\title{
PRODUÇÃO DE SEMENTES DE ALFACE EM CULTIVO HIDROPÔNICO
}

\author{
LETTUCE SEEDS PRODUCTION IN HYDROPONIC SYSTEM
}

\author{
Nilson Lemos de Menezes ${ }^{1}$ Osmar Souza dos Santos ${ }^{2}$ Denise Schmidt ${ }^{3}$
}

\section{- NOTA -}

RESUMO

\begin{abstract}
Sementes de alface das cultivares Deyse e Regina foram produzidas em estufa, no sistema hidropônico, com elevados rendimentos por planta e boa qualidade de sementes quando comparados a resultados de sistema convencional, de canteiros em campo. Esses dados sugerem estudos de produção de sementes de alface em cultivo protegido.
\end{abstract}

Palavras-chave: Lactuca sativa, hidroponia, produção de Sementes.

\section{SUMMARY}

Lettuce seeds of Deyse and Regina cultivars were produced in greenhouse, in hydroponic system, with excelents rendiments per plant and seed quality, when compared to conventional systems, of parcels in field. This results recommend studies in lettuce seeds production in greenhouse.

Key words: Lactuca sativa, hidroponic system, seed production.

A alface (Lactuca sativa L) é uma hortaliça folhosa, pertencente à família Cichoriaceae de grande aceitação na alimentação humana por ser boa fonte de vitaminas (A1, B1, B2 e C) e sais minerais (Cálcio e Ferro). Sua multiplicação se dá por meio de sementes, e o consumo no Brasil é superior a 50t/ano (GUEDES $\boldsymbol{e t}$ al., 1988; NASCIMENTO, 1991). Esses dados, no entanto, não consideram o uso de sementes peletizadas, nem a formação de mudas em bandejas, no qual se reduz muito a quantidade de sementes por hectare.
Apesar da disponibilidade de cultivares com boas características e da existência de regiões favoráveis à produção, grande parte das sementes utilizadas e' importada, devido à falta de incentivo e de tecnologias adequadas à produção de sementes. Isto sugere estudos sobre a produção de sementes de alface em cultivo protegido, no qual se tenha maior controle sobre o ambiente e, consequentemente, boa quantidade e qualidade.

O ciclo das alfaces cultivadas no Brasil, para a produção de sementes, varia em função do clima, cultivar e local, podendo alcançar 120 a 170 dias. Em cultivo protegido, esse período se reduz para 100 a 120 dias. Na região Sul, a semeadura pode ser realizada na primavera, a partir do final de setembro. Devido a controles de temperatura, umidade e luz que podem ser executados nas estufas, talvez se possa realizar mais de um ciclo de produção de sementes por ano.

Nos canteiros dentro das estufas, utilizamse espaçamentos que variam de 60 a $80 \mathrm{~cm}$ entre as filas, por 30 a $40 \mathrm{~cm}$ entre as plantas, estabelecendo populações de 60.000 a 80.000 plantas por hectare, porém no sistema hidropônico são utilizados espaçamentos reduzidos, tais como $25 \times 25 \mathrm{~cm}$ ou $25 \times 30 \mathrm{~cm}$, que necessitam ser confirmados como indicação para produção de sementes. Os espaçamentos utilizados para a produção de sementes parecem não afetar a produção por área (DONI FILHO, 1982), no entanto, os menores espaçamentos resultam em colheitas antecipadas.

\footnotetext{
${ }^{1}$ Engenheiro Agrônomo, Doutor, Professor Adjunto, Departamento de Fitotecnia, Universidade Federal de Santa Maria (UFSM), 97105 900, Santa Maria, RS. Bolsista do CNPq. E-mail: nmenezes@ccr.ufsm.br. Autor para correspondência.

${ }^{2}$ Engenheiro Agrônomo, Doutor, Professor Titular, Departamento de Fitotecnia, UFSM, 97105-900, Santa Maria, RS. Bolsista do CNPq.

${ }^{3}$ Engenheiro Agrônomo, Doutorando do Programa de Pós-graduação em Agronomia, UFSM

Recebido para publicação em 11.04.00. Aprovado em 01.11.00
} 
Em canteiros de áreas abertas, recomenda-se isolamento mínimo de $30 \mathrm{~m}$, para produção de sementes fiscalizadas, ampliando-se para 90m, para sementes básicas. Nos cultivos dentro de estufas, basta manter uma cultivar por unidade, fechando as estufas vizinhas, no horário de maior ação dos insetos, no período de polinização.

A colheita das sementes de alface acompanha sua maturação desuniforme, por isso recomenda-se a colheita das sementes, das inflorescências maduras ou plantas inteiras. A maturidade da semente é caracterizada pelo aparecimento de pêlos brancos sobre os floretes. A colheita de sementes maduras consiste em bater as plantas sobre um coletor de pano, colocado entre as linhas. Pode-se iniciar este processo a partir de $30 \%$ de sementes maduras na inflorescência e repetir essa operação quantas vezes forem necessárias até completar a colheita. $\mathrm{O}$ corte manual de inflorescências ou plantas pode ser executado quando estas apresentam de 60 a $70 \%$ de plumagem branca.

O rendimento é bastante variável, dependo da cultivar e do local de produção. Estudos realizados no Laboratório de Hidroponia, do Departamento de Fitotecnia/UFSM, indicaram a possibilidade de produção de sementes em estufa, no sistema hidropônico.

Foram estudadas as cultivares Deyse e Regina. A primeira apresenta maturação uniforme, fato que permitiu uma única colheita e percentagem de germinação das sementes de $98 \%$. A cultivar Regina, de maturação desuniforme teve a colheita executada de duas maneiras: na primeira, colheramse as inflorescências maduras em cinco momentos diferentes, num intervalo de nove dias, acompanhando a maturação das sementes, obtendose rendimento por planta correspondente a $320 \mathrm{~kg} \mathrm{ha}^{1}$ e germinação das sementes de 99\%; o segundo modo de colheita executado para essa cultivar foi o corte das plantas num único momento, com todas as inflorescências maduras. Verificou-se que esse segundo modo aumentou em $97 \%$ a produção de sementes $\left(633 \mathrm{~kg} \quad \mathrm{ha}^{1}\right)$, sem alterar-lhes a germinação. Esse resultado se deve, provavelmente, às condições de cultivo no sistema hidropônico, onde não ocorrem insetos-praga, ventos ou movimentação das plantas, antes da colheita, que foi efetuada planta por planta. $\mathrm{O}$ menor manuseio manteve as sementes na planta evitando a degrana precoce e as perdas durante a colheita, que são comuns e elevadas nos outros métodos de colheita.

Os rendimentos estimados estão apresentados na tabela 1, juntamente com os rendimentos médios indicados por VIGGIANO
Tabela 1 - Rendimento médio de sementes de alface em sistema hidropônico (em estufa) e sistema convencional (em canteiros). Santa Maria, RS, UFSM, 1999.

\begin{tabular}{llc}
\hline & \multicolumn{2}{c}{ Rendimento $\left(\mathrm{kg} \mathrm{ha}^{1}\right)$} \\
\cline { 2 - 3 } Cultivar & Hidropônico & Convencional* \\
\hline Regina & --- & 270 \\
Regina (Colheira da Planta Inteira) & 633 & --- \\
Regina (Colheita das Inflorescências) & 320 & --- \\
Piracicaba 65 & --- & 203 \\
Deyse & 340 & --- \\
Grand Rapids Nacional & --- & 630 \\
\hline
\end{tabular}

*Fonte: VIGGIANO, 1990

(1990), autor que não apresenta a origem dos dados. Observa-se que aqueles estimados no sistema hidropônico, nas condições de Santa Maria-RS, são comparáveis e até superiores aos verificados no sistema convencional de produção em campo.

A qualidade fisiológica e sanitária das sementes de alface, produzidas no campo, está diretamente relacionada às condições de clima e solo em que são produzidas; neste caso, a redução da precipitação nas fases de maturação e colheita é fundamental. No cultivo em estufa, no sistema hidropônico, as variações climáticas são menores e o controle da irrigação é completo. Pode-se suspender a solução nutritiva a partir da maturidade fisiológica para as cultivares de maturação uniforme ou programá-la para aquelas em que a maturação se estende por um período maior, desse modo garantindo boa qualidade das sementes.

\section{REFERÊNCIAS BIBLIOGRÁFICAS}

DONI FILHO, L. Produção de sementes de alface. In: MULLER, J.J.V.,CASALI, V.W.D. (Ed.). Seminários de olericultura. 2 ed. Viçosa: UFV, 1982. V.2, p.207-255.

GUEDES, A.C., MOREIRA, H.M., MENEZES, J.E. Produção e importação de sementes de hortaliças no Brasil1981/1985. Brasília : EMBRAPA/CNPH, 1988. 141p.

NASCIMENTO, W.M. Situação da produção e importação de sementes de hortaliças no Brasil. In: ENCONTRO SOBRE PRODUÇÃO E QUALIDADE DE SEMENTES DE HORTALIÇAS. Brasília, 1991. Anais... Brasília: EMBRAPA-CNPH, 1991. 151p. p.1-10.

VIGGIANO, J. Produção de sementes de alface. In: CASTELlANE, P.D., NICOLOSI, W.M., HASEGAWA, M. (Coord.). Produção de sementes de hortaliças. Jaboticabal: FCAV/FUNEP, 1990. 261p. p.1-13. 